\title{
BUSINESS MODEL INNOUATION THROUGH THE USE OF DIGITAL TECHNOLOGIES: MANAGING RISKS AND GREATING SUSTAINABILITY
}

\author{
Dragoș Tohănean $^{1 *}$, Alexandru Ilie Buzatu ${ }^{2}$, Cristina-Andrada Baba ${ }^{3}$ \\ and Bogdan Georgescu ${ }^{4}$ \\ ${ }^{122) 344)}$ The Bucharest University of Economic Studies, Romania
}

\author{
Please cite this article as: \\ Tohănean, D., Buzatu, A.I., Baba, C.A. and Georgescu, B., \\ 2020. Business Model Innovation Through the Use of \\ Digital Technologies: Managing Risks and Creating \\ Sustainability. Amfiteatru Economic, 22(55), pp. 758-774.
}

Article History:

Received: 30 March 2020

Revised: 12 May 2020

Accepted: 5 June 2020

DOI: $10.24818 / \mathrm{EA} / 2020 / 55 / 758$

\begin{abstract}
In order to gain competitive advantages and maintain high market shares, businesses have to constantly adapt, not only by implementing the latest technology available, but also by creating their own innovations, aiming to make the business both more profitable and more sustainable. Changing the business model by introducing technological and sustainable components puts companies at high risk.

On the one hand, medium-sized companies are more flexible, the decision-making process is quicker, and they can more easily adopt change-management strategies, but on the other hand they are more vulnerable to market changes and dependent on constant financial flows. This article analyses the entrepreneurial behaviour of 92 technology-based companies in the European business market through online and face-to-face questionnaires to understand how they generate economic growth by successfully implementing sustainable innovations while avoiding predictable risks and preparing for the unpredictable ones, but also to provide a best-practice guide for likewise companies facing that process.

At the same time, for a better understanding of the changes of medium-sized companies, the research is comparing the Eastern and Western Europe. There are not only visible differences in form and style between Eastern and Western European companies, but also differences in risk management, perception of innovation, organization of the business model.

The novelty of this study comes from the comparative approach of the two areas in terms of innovation, sustainability and risk management, by highlighting the advantages and disadvantages they face, and by establishing the principles that could make companies in both areas more competitive, being aware of the measures they should take.
\end{abstract}

Keywords: innovation, business models, risk management, European companies, digitization, technologies, sustainability

JEL Classification: G32, M00, M16, O30, Q56

\footnotetext{
*Corresponding author, Dragoș Tohănean - tohanean_dragos@yahoo.com
} 


\section{Introduction}

Technologies, methods and people are imperative challenges for companies. Technological trends are driving dynamic changes in the digital future. In addition, trends in information technology (IT) are forcing companies to be agile and implement new innovative business models and various business adaptation processes (Lambert et al., 2018) but which are not lacking challenges. In order to continuously innovate the business model, all challenges must be understood and adapted based on business strategy and market demand. (Tohanean, et al., 2019).

The importance of investing in digitization and digitalization is recognized globally and economically. Companies tend to realize their importance and consider it necessary to invest in digital tools, as a long-term partnership (Sahut and Peris-Ortiz, 2014) to increase research and development (R\&D) capacity, as well as to reduce risks (Ungureanu, et al., 2016). The purpose of investing in innovative tools or processes is to develop sustainable business, creativity, prosperity, create new jobs, increase the quality of life and prepare for market changes that influence the business. Although, there are different approaches to innovation depending on the historical and political background, public policies and the existing level of development (Kallaste, et al., 2018), this study shall analyse in comparison the Eastern and Western approach to innovation and risk management (Pelau and Chinie, 2018).

Business innovation has been analysed by authors from different perspectives (Vasiliu and Cercel, 2015), Bhattacharya, et al. (2017) consider that the uncertainty of a policy or a country is a main factor influencing innovation, Taalbi (2017) considers that innovation is actually the answer to problems and is a process of adaptation, rather than a result of industrialization or technological development, while Audretsch, et al. (2016) consider that technology is the key to innovation. In turn, Foss and Saebi (2016) consider that innovation comes from adaptations of business models. Regardless of the innovation source, the principle that remains valid for any field is that of sustainability, which is no longer a deliberate decision, but has become an imperative component in business (Schepers, 2017), developed as a new science, that of risk management.

Although innovation, digitalization and sustainability are topical areas both separately researched and addressed together, the studies are conducted generally and are not applied in a specific region. This article complements the others by conducting a comparative study between Eastern Europe and Western Europe. The authors want to determine whether the two areas can be approached uniformly in the context of the three concepts, namely innovation, digitalization and sustainability, or whether they represent considerable differences that require a differentiated approach.

The result of this research aims to support Eastern European companies in the updating process of the business model, by using appropriate strategies to transform the business into a more sustainable and digitized one with the help of technology. In order to conceptualize the specificity of Eastern Europe area and be able to implement the results in practice, the authors have compared the three concepts in Eastern and Western Europe and designed a best-practice guide outlining the steps to be taken to improve the business model in this regard, as well as to avoid business risks.

\section{Literature Review}

Today's corporate environment is characterized by a high degree of complexity and increased dynamism. The main challenges and economic evolutions affecting every company are: very short product life cycles, unpredictable buying behaviour changes, increased competition, 
financial market turbulence and declining economy (Fisher, et al., 2015). But those who keep markets under observation, interview customers, evaluate analyses, i.e. explore risks and opportunities, continuously adjust their strategy and invest in sustainability, can ensure the company's growth despite the impediments. Many authors have researched the topics of innovation, risk management and business sustainability, trying to define and discover the sources of radical innovation, which are able to help companies maintain a competitive advantage on the market and ensure their level of activity, avoiding predictable risks, as well as preparing for imminent challenges.

In literature, innovation can be classified according to the degree of novelty, the type of innovation or the source of innovation (Souto, 2015). Regarding the degree of novelty, we differentiate the radical innovation from the incremental one (Kobarg, et al., 2019). The first one, refers to absolute change, defines a creative approach and is completely new from what was until then. Radical innovation is the one that leads to development and evolution, is able to influence a large number of other businesses and sectors and brings a considerable advantage to the owner. The latter has a low degree of novelty. Incremental innovation is based on technologies, knowledge and research that are already existing and available.

In terms of the type of innovation, technological innovation can be differentiated from nontechnological innovation. The first one is mainly dominated by suppliers, it refers to innovations developed by external stakeholders that could be implemented and adapted in different sectors. Technological innovation is essential for businesses to stay competitive. But as effective it might be, it is still considered to be a means to maintain the company's activity at an optimal level or to achieve an incremental innovation and is less considered to be the key to a competitive advantage. Technology, especially if developed outside the company, is easy to be taken over by competitors, the reason for which a more innovative type, that could lead quicker to a radical change, is the non-technological one, which happens rather inside the company and which is individualized. This category includes both the business model and the innovation of the business concept (Geissdoerfer, et al., 2018).

We differentiate product, process or organization innovation. Product innovation refers to new, improved services or products based on reliability, quality, materials, technology, size or design, which are collected from market feedback and reactions. Most companies actively improve their products and services, being the most common type of innovation, but with the lowest degree of novelty (Berends, et al., 2013). Process innovation refers to an investment in digitization or digitalization, an improvement of the technological line, an adjustment of the supplier chain or adjustments of the system that lead to increased sustainability (Schaltegger, et al., 2012). This type of innovation brings a greater degree of novelty (Boer, 2001), therefore, the effects are also more significant for the company and some changes may even reach the threshold of generating radical innovations (Clark and Stoddard, 1996). The main advantages are cost optimization, labour reduction, energy saving and increased production capacity (Mantovani, 2006). Organizational innovation is the most complex and radical of those listed above. It affects business practices, external relations, workplace organization, the distribution of responsibilities through the division of labour and even the diversification of business activities. Organizational innovation influences the business model and generates the highest degree of novelty, which can offer competitive advantages (Boer and Durant, 2020).

As product or service innovation is more likely to be imitated by competitors and does not always deliver the desired result (Nylén and Holmström, 2015), firms try to focus on 
sustainable competitive advantages (Teece, 2010) through non-technological innovation, organizational innovation, which is why they need to get a deep understanding of the business model (Lu and Liu, 2016) and the customer.

With the introduction of philanthropy as form of sponsorship, there has been a schism in the way businesses operate and the role they play in society. Since then, the level of involvement of companies in society and environmental issues has steadily increased, introducing the principle of corporate social responsibility (CSR) in the company's business model and the creation of companies based on social entrepreneurship. Currently, the pressure exerted on companies, enhanced by the expectations of customers and stakeholders, places sustainability at the top of priorities and the sustainable goals of a company are introduced even in its mission and vision (Joyce and Paquin, 2016). The responsibility shown by companies does not stop on the environment and the social component, but extends to all 17 sustainable development goals formulated by the United Nations (United Nations, 2020.). Assuming a sustainable development of a business must sometimes limit the degree of innovation it adopts, when it does not maintain an ethical balance, but even so, the growing interest in sustainability should not be seen as an impediment to the possibilities of innovation, but rather as an opportunity. New business opportunities are created, and stakeholders are more eager and attracted to responsible business (Bocken, et al., 2014).

Any change in the business environment and any development attempt is associated with a certain degree of risk. Some risk situations could be predicted and avoided, while others could not, which is why the company must be agile and ready to deal with unknown situations (Mateescu, et al., 2019). Risk management is understood by measuring and controlling all business risks in the company. Entrepreneurial risk means a risk that any entrepreneur assumes when starting a business. From an entrepreneurial point of view, all dangers and uncertainties that threaten economic actions and thus economic success are risks (Sadgrove, 2015). In order to systematically identify and record the areas of activity relevant for risk prevention, the science of risk management is introduced. It is designed to help corporate management identify and manage significant risks that could jeopardize the company's success or existence over a period of time (Olivia, 2016). As part of corporate management, it assumes the task of developing and implementing risk limitation strategies, while optimizing profits. The purpose of risk management is not to eliminate all risks, otherwise the chances of success could be missed. The goal is to find an optimal relationship between opportunities and risks, based on the decision-maker's risk preferences (Meidell, 2017).

Risks are inevitable during the innovation process. As innovation strategies based on risk avoidance are not an option, proactive risk management is needed. If risks are identified in the early stages of business innovation, then there is sufficient time for them to be avoided (Cooper and May, 1976; Cooper, 1979, 1981, 1993; Wheelright and Clark, 1992). In addition to the importance of early risk identification, Mishra, et al. (2019) suggest that risk assessment and prioritization could lead to even better risk management.

Innovation and sustainability are increasingly approached together. Both areas are currently a priority for companies (Kennedy, et al., 2017). Approached separately, it is possible that the two areas will contradict each other and the result will have a negative impact on the company: financial losses, conflict of interest, incorrect market positioning. If approached together, innovation is used to increase the company's profitability through sustainable solutions, and the company grows perfectly and manages resources optimally (Wagner, 2017). 
A certain level of risk is found at all levels of a business and in all periods of its development, especially in periods when the business is implementing changes. However, the risk assumed by a company can be controlled and managed to a certain extent. While some companies minimize risk, other companies largely embrace it (Zhao, et al., 2020). The risk is directly proportional to innovation, which is related to sustainability. Therefore, companies have the opportunity to reduce risks and evolve much more slowly or they can throw themselves into battle and manage all three areas in parallel (Temel and Vanhaverbeke, 2020). In the following lines, we will present the results of a desk research that motivates the attitude towards risk depending on the emerging area of the company.

\section{Innovation, Technology and Risk: Business Models from Eastern and Western Europe}

There have always been differences between Western and Eastern Europe, be it at the economic, geographical or business level. Comparing the per capita income of European countries, there are striking differences. For example, in Bulgaria, the annual per capita income in 2019 was 8,130 EUR, in Portugal 22,687 EUR and in Norway 101,222 EUR (Eurostat, 2019). One difference is particularly striking, namely the one between Eastern Europe and Western Europe. In the east, per capita income does not exceed 20,000 EUR in any country, but it does so everywhere in the west (Eurostat, 2019).

How can the east-west difference be explained? The question is not just of academic interest. It is also about making a realistic forecast. Will the East soon be able to shorten its distance from the West or will it hardly change in the near future?

The difference between Eastern and Western Europe was already very clear in the Middle Ages. At that time, the West was in the midst of an economic boom, which was reflected, in particular, in the upswing in cities (e.g., Paris, London, Rome, Florence, Milan and Palermo). In the east, this trend happened relatively little, the economy remained agricultural and there were few shopping centres. In Western Europe, the trade boom also had beneficial institutional consequences. In the west, cities helped new forms of political self-organization, while in the east, large estates remained dominant. In the West, there was already a first wave of liberation of the peasants in the Middle Ages, as cities served as a refuge ("the air of the city makes people free"), while "serfdom" was tightened in the East. Russia, for example, only lifted it in the middle of the $19^{\text {th }}$ century (Khan Academy, 2020). Starting from this difference that was built many years ago, it is also outlined when we talk about business models.

A business model describes how a company's mechanisms and processes work together to generate value for a particular target market and convert this value proposition into sales. The result can consist of products, services or a combination of both. This simplifies the description of these mechanisms, and the business model can be divided into different components (e.g., value creation processes, target groups, profit models, etc.) (Chambers and Patrocinio, 2011). A business model describes the essential characteristics of a company by answering four key questions:

- What are the advantages of customers or partners? (Added value);

- In what resource configuration is the service created? (Resources);

- How is the service created? (Organization and value chain);

- How is money made? (Capital and financial resources).

For the business model, innovation and sustainability are like oxygen for people. Without the power of new ideas and long-term/stable visions, we are not able to live and develop. 
Innovations are understood to mean successful, newly launched offers on the market. Originally related to products and services, innovations can now also refer to processes, organizational structures or entire business models. Therefore, an innovation of the business model represents a significant change in the characteristics of a company that better satisfies the needs of customers than the original business model, through new forms or combinations of the components mentioned above. Business model innovations can either be completely newly developed or further developed business models.

If we have a big picture over Europe, we recognize that the following sectors register the highest growth: information and communication, administrative / support service activities, transportation and storage. The wealthiest companies in Europe have main activities in industries such as "oil and gas" or "financial services", companies such as: Royal Dutch Shell, Total, Volkswagen, E. ON, ING or Gazprom. Most of them are in Western Europe in countries like the Netherlands, United Kingdom, France, Germany or Italy (Global Database, 2020). From the top 10 companies (divided by revenue) only one is in Eastern Europe

In 2018, the EU-28's business economy was made up of 27.5 million active enterprises with more than 150 million persons employed. The largest active enterprise "population" was registered in Italy and France (both 3.8 million), followed by Spain (3.0 million), Germany ( 2.8 million) and the United Kingdom ( 2.6 million). The services sector was dominant in every country, measured by the highest proportion of active enterprises (Eurostat, 2019).

Based on data from 2018, there were about 3.9 million jobs created from 2.7 million newly born enterprises. The number of newly born enterprises in 2018 increased by about 20000 enterprises compared with 2016. The one-year survival rate for enterprises created in 2016 was more than $80 \%$. The highest shares of enterprises in 2018 were reported in Ireland, Spain and Portugal. If we take Western or Eastern Europe as starting points for a business model comparison, the main point is clear. From all active enterprises, the service sector is the most common business model found (Global Database, 2020). Services or business models such as: subscription-based activities, meal delivery services, virtual reality accessories, online education, fitness technology, artisan food trucks, anger rooms, electronic bicycles, translation / foreign language platforms or living green / off-grid. The highest birth rates of these companies are in Eastern Europe, in countries such as Slovakia, Hungary, Estonia, Romania, Slovenia or Poland. (Global Database, 2020). In addition, the newly created companies are also measured by the survival rate, some of which have survived from one to three years - but most are still present on the European market. Most are in Western Europe, represented by countries such as the Netherlands, Belgium or Austria. However, there are also companies from Eastern Europe with a survival rate of more than 5 years, such companies can be found in Romania, Poland or Bulgaria. (Global Database, 2020).

When it comes to business model innovation or sustainability, Western Europe is more oriented to tradition and history - where Eastern Europe is more oriented to innovation, risks, new approaches and attempts (Tohanean, et al., 2018). The direction in Eastern Europe is more to try new things and learn from mistakes - Western Europe is more "old school" when it comes to open or innovate business models.

According to a study carried out at the request of the European Commission through the DigitaliseSME pilot project (2020), the level of awareness of digitalisation and the reasons why companies invest in technology is very high. Activities such as invoice management, business model change, general marketing, acquiring new customers, data management or internal processes have changed significantly. 
The turbulent nature of the business environment is detrimental to open innovation and the acquisition of new technologies. It is important that each company does not aim to reduce development costs, but to pursue optimization and to include in its development strategies investments in new technologies, software solutions or robotic systems for repetitive processes. Innovation, sustainability and technology are present at all levels of companies and represent key pillars of all business models in Western and Eastern Europe.

\section{Research Methodology}

Based on the results of the desk research and the information collected about Western and Eastern companies, the authors apply a questionnaire to verify and support these findings. The first part of the paper will present what innovation means, what are the current findings of the literature and the fact that no innovation strategy can be implemented while completely avoiding risks. The purpose of this study is to answer the following questions: What is the level of awareness and reasons for investing in technology? What processes need to be improved with digital solutions? What are the best practices to avoid the risks associated with threats from technologies and digitization processes? The authors use a secondary research method, namely the case study and a survey which is a method of exploratory quantitative research by applying online questionnaires.

In this sense, the results of an exploratory study will be presented. In order to analyse the relationship between changing operations using digital tools, innovation activities, performance and ownership structure, we used the survey method and applied online questionnaires. They show us the level of understanding towards using digital tools for increased performance, to discover weak processes, digital knowledge at every level of a company in developing economies and allow us to monitor the endogeneity between innovative activities, calculated risks and there is management at the level of entrepreneurial enterprises or international affairs. It is a vague and illogical phrase! The individual interview is a valuable method of understanding people's perceptions, understandings and experiences of a given phenomenon and can contribute to in-depth data collection (Frances, 2009). To achieve the objectives of the paper and to verify the literature on the local market, a series of offline questionnaires were applied with some of the local entrepreneurs, from technology-based companies, as well as an online survey. In total, 92 respondents from the local business market, with different sizes, answered a series of questions on innovation, investment in technology, knowledge of the concept of global competitiveness and other relevant topics, which shows us the understanding level of the use of digital tools to increase performance, discover weak processes, the level of digital knowledge at all levels of a company in developing economies. At the same time, the data collected allow to monitor the endogeneity between risk management and innovative activities in entrepreneurial enterprises or international enterprises. A quantitative method was chosen in order to obtain more information from several respondents from entrepreneurial enterprises or from international enterprises.

The survey was conducted over a period of 4 months, from September 2019 to December 2019. Part of the research took place face to face at the company's headquarters, but most of the interviews were conducted online, via Skype or telephone. An unlikely sampling method called the "snowball" method was used. In the first stage, 10 companies were selected randomly and then asked to recommend other companies to a total of 92 . 
The structure of the sample is presented below in terms of the number of employees, the size of the turnover and the field of activity. The size of the companies interviewed according to the number of employees is as follows: $30.2 \%$ ( 1 to 10 employees), $20.9 \%$ (11 to 50 employees), $9.3 \%$ (51 to 100 employees) and $39.5 \%$ (over 101 employees). The size of the companies interviewed according to the size of turnover (million EUR) is as follows: $25.6 \%$ (from 0 to 0.2 million EUR), 14\% (0.2 to 1 million EUR), $11.6 \%$ (1 to 4 million EUR), 9.3\% (4-20 million EUR) and 39.5\% (more than 20 million EUR). The size of the interviewed companies according to the field of activity is as follows: $14 \%$ (retail/distribution), $2.2 \%$ (import / export), 14\% (industrial production), 16.3\% (IT production: software and hardware) and $53.5 \%$ (different service areas). The results are used to understand what investments are needed to be made in digital technologies to improve the company's performance (gain a competitive advantage), to analyse best practices to avoid the risks associated with technology threats (digitalization processes), to identify whether companies are implementing sustainable development strategies and whether they are open to innovation and technology and what is needed to develop sustainability.

\section{Research Results}

The analysis indicates quite large differences in the approach to the strategy of digitalization of information flows within companies. The differences are obvious, whether we are talking about integrated management solutions, cloud migration, automation of repetitive processes within companies or suitable for the implementation of digital solutions. The strategic approach of investing in digital solutions shows differences in thinking and financial budgeting, depending on the size of the company. Every company, regardless of its size, goes through changes aimed at developing the business in a sustainable way. The influence of competitiveness in a global market, as well as the development (optimization) of internal or external connections in an organization can bring a competitive advantage and can create a framework for the development of sustainable business.

The survey shows a greater interest (74.4\% of the companies interviewed) for strategic planning and international development. These companies want to develop their ability to maintain all their activities at a certain pace or level. For the development of sales on new markets, internationally, in a sustainable way, the activities of companies are supported by patents, the acquisition of research and development equipment and help to open to new domestic processes.

The survey shows that respondents who invest in digital tools in order to develop more agile practices are likely to report that expectations of digital transformation efforts are at the forefront of their business and investment plan, wanting to achieve more and bring innovative business solutions by developing internal creativity.

With all the technological change and influence on business models, more and more companies tend to change or create new business segments and develop sustainable directions. The research shows a greater interest for large companies to change their business and move their processes more and more towards online development and a shared interest for small and medium enterprises to develop more offline processes in their business, especially in the retail area. 
The research shows how companies invest in digital solutions or in part of the processes for companies that are already "online":

- $41.9 \%$ of the interviewed companies digitized $25 \%$ of the processes;

- $30.2 \%$ have $50 \%$;

- $7 \%$ have $75 \%$;

- $20.9 \%$ of the companies have complete $(100 \%)$ "online" solutions.

Here we can see a shift from the human to the digital approach, bringing new skills to the business market, especially in the field of digital knowledge. Interviews with entrepreneurs and managers show that investment budgets for digitalization or digitization are different depending on the size of the enterprises. SMEs invest between 1-1.5\% of turnover, and large companies' investments for automation and process improvement will go up to $3 \%$ of turnover.

A McKinsey survey (2018) shows that a company aims to achieve better results, but the results of digital transformation seem independent, regardless of the field of transformation: stronger customer relationships, more sales through digital channels, better quality offers or smaller operating costs.

For a sophistication in this approach, however, the use of automation is a new capability for all natives except digital ones, which vary accordingly. Companies need to develop more and more new digital knowledge and skills among their employees. The research carried out strengthens the McKinsey report (2018) and can be seen in figure no. 1, that for an increase in competitiveness, companies have a similar understanding, and the two most important pillars for a competitive company are: investment in employees (specified in $72.1 \%$ of responses) and investment in quality services (mentioned in $65.1 \%$ of cases). Another interesting fact from the survey is how companies understand that in order to increase knowledge and competitive advantage it is important to invest in the continuous development of employees to increase efficiency and create a performance-oriented culture $(81.4 \%)$ and value-added products or services for the consumer $(72.1 \%)$.

These two questions reflect how companies understand that for a sustainable development and a competitive advantage, without increasing operating costs, they must train new skilled employees and invest in services that increase customer satisfaction. The results shall highlight how companies will seek to achieve all this with the help of digital tools and invest in new technologies.

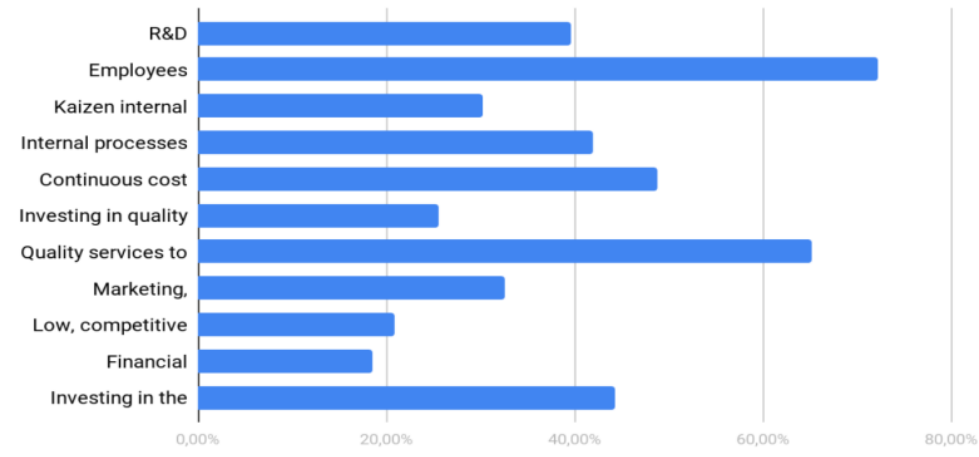

Figure no. 1. An investment strategy to increase competitiveness 
Regarding sustainable development (figure no. 2), opinions are divided, and entrepreneurs or managers believe that for sustainable development, largely internationally, companies must invest in the development of internal values for the continuous improvement of processes and procedures $(67.4 \%)$, standardization of processes and procedures $(55.8 \%)$ and investments to create an innovative environment $(55.8 \%)$.

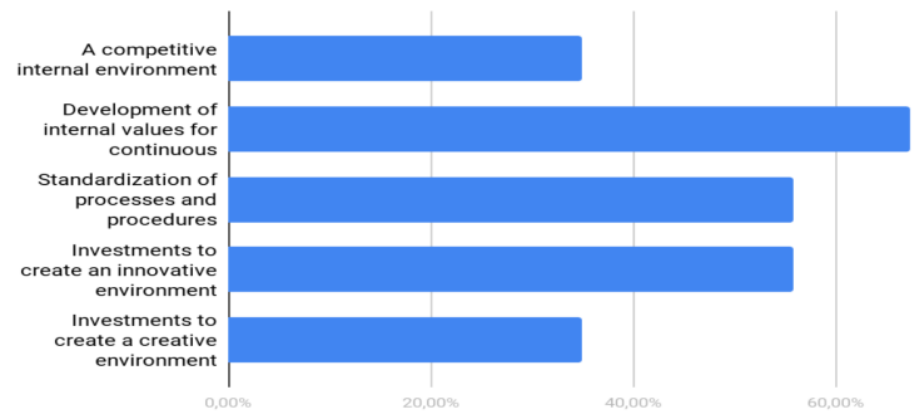

Figure no. 2. Sustainable business development strategy

The results of the survey were analysed with a series of correlations and cross-tabulations, with significant results. In relation to the research objectives of this paper, the authors made a series of analyses with the correlation between the questions related to the interests of the competitive advantage, digital transformation and risk management.

As you can see in table no. 1, the reference calculation brings interesting results, according to which companies differ in the way they think and prepare for risks during the business life. Out of the companies surveyed, 50 of the companies that have a risk mitigation plan know how to manage every case of risk developed in business life, while only 8 of them have a plan for risk situations, but do not develop a management system for encountered risks. Fourteen of them have no risk management plan or method. This shows that these companies have a very poor preparation for any business risk and that they are vulnerable to changes inside or outside the business.

Table nr. 1. Risk Management and Risk Plan Crosstabulation

\begin{tabular}{|cc|c|c|c|}
\hline & & \multicolumn{2}{|c|}{ Risk Plan } & \multirow{2}{*}{ Total } \\
\cline { 2 - 5 } & yes & no & \\
\hline \multirow{2}{*}{ Risk Management } & yes & 50 & 20 & 70 \\
\cline { 2 - 5 } & no & 8 & 14 & 22 \\
\hline Total & 58 & 34 & 92 \\
\hline
\end{tabular}

The analysis continues with indicators specific to the topic of the paper and analysed by the authors for the risk analysis and management. As you can see in table no. 2, relatively few companies (32) are prepared for the current financial and socio-political risk, while quite a few of them (30) do not take these factors into account, which shows a very high risk for the liquidity of these companies or management plans in case of a financial or external crisis that is independent of the company's activity. 
Table no. 2. Financial Risk and Socio-political Risk Crosstabulation

\begin{tabular}{|lc|l|l|l|}
\hline \multirow{2}{*}{} & & \multicolumn{2}{|l|}{ Socio-Politic Risk } & \multirow{2}{*}{ Total } \\
\cline { 3 - 5 } & & yes & no & \\
\hline $\begin{array}{l}\text { Financial } \\
\text { Risk }\end{array}$ & yes & 32 & 26 & 58 \\
\hline Total & 4 & 30 & 34 \\
\hline
\end{tabular}

The authors made a series of correlations to show the consistency of the answers regarding the impact factors in the business life, and the results show moderate to strong relationships in these cases (see table no. 3).

Table no. 3. Correlations between Risk Management, Risk Plan, Financial Crisis and Socio-political Risk

\begin{tabular}{|l|l|r|r|r|r|}
\hline \multicolumn{2}{|l|}{ Variables } & \multicolumn{3}{c|}{ Values of the Correlation Coefficient } \\
\hline \multirow{2}{*}{ Risk Management } & Pearson Correlation & 1 & $.310^{* *}$ & $.310^{* *}$ & $.449^{* *}$ \\
\cline { 2 - 6 } & Sig. (2-tailed) & & .003 & .003 & 0 \\
\hline \multirow{2}{*}{ Risk Plan } & Pearson Correlation & $.310^{* *}$ & 1 & $.533^{* *}$ & $.522^{* *}$ \\
\cline { 2 - 6 } & Sig. (2-tailed) & .003 & & 0 & 0 \\
\hline \multirow{2}{*}{ Financial Crisis } & Pearson Correlation & $.310^{* *}$ & $.533^{* *}$ & 1 & $.429^{* *}$ \\
\cline { 2 - 6 } & Sig. (2-tailed) & .003 & 0 & & 0 \\
\hline \multirow{2}{*}{ Socio-Politic Risk } & Pearson Correlation & $.449^{* *}$ & $.522^{* *}$ & $.429^{* *}$ & 1 \\
\cline { 2 - 6 } & Sig. (2-tailed) & 0 & 0 & 0 & \\
\hline
\end{tabular}

Note: ** The correlation is significant at the significance threshold of $1 \%$ (2-tailed).

As you can see in table no. 4 the reference situation brings interesting results, through which companies understand the advantages brought by new technologies, and the business must invest in these tools. Most of the companies surveyed have knowledge and understanding of these needs, where 62 of them have a digitalization plan and are investing in this direction, and 20 of them do not have a plan and have not started investing. An interesting result shows that 8 of the companies invest in digital tools, but without a digitalization plan and this shows the lack of knowledge, waste of finances and probably high risk for the low efficiency of the results after the implementation of these tools.

Table no. 4. Crosstabulation between Digitalization plan and Investment in Digitalization

\begin{tabular}{|lc|r|r|r|}
\hline \multirow{2}{*}{} & \multicolumn{2}{|c|}{$\begin{array}{c}\text { Investment in } \\
\text { Digitalization }\end{array}$} & \multirow{2}{*}{ Total } \\
\cline { 2 - 4 } & \multicolumn{2}{|c|}{ yes } & \multicolumn{1}{|c|}{ no } & \\
\hline \multirow{2}{*}{ Digitalization } & yes & 62 & 2 & 64 \\
\cline { 2 - 5 } & no & 8 & 20 & 28 \\
\hline Total & 70 & 22 & 92 \\
\hline
\end{tabular}

The authors made a series of correlations to show the consistency of the answers, regarding the impact factors in business life, cost reduction, business and operational efficiency. The results show strong relationships in this case (see table no. 5). 
Table no. 5. Correlations between Digitalization, Digitization and Investment in Digitalization

\begin{tabular}{|l|l|r|r|r|}
\hline \multicolumn{2}{|c|}{ Variables } & Values of the Correlation Coefficient \\
\hline \multirow{2}{*}{ Digitalization } & Pearson Correlation & 1 & $.807^{* *}$ & $.737^{* *}$ \\
\cline { 2 - 5 } & Sig. (2-tailed) & & 0 & 0 \\
\hline \multirow{2}{*}{ Digitization } & Pearson Correlation & $.807^{* *}$ & 1 & $.661^{* *}$ \\
\cline { 2 - 5 } & Sig. (2-tailed) & 0 & & 0 \\
\hline \multirow{2}{*}{$\begin{array}{l}\text { Investing in } \\
\text { Digitalization }\end{array}$} & Pearson Correlation & $.737^{* *}$ & $.661^{* *}$ & 1 \\
\cline { 2 - 5 } & Sig. (2-tailed) & 0 & 0 & \\
\hline
\end{tabular}

Note: **. The correlation is significant at the significance threshold of $1 \%$ (2-tailed).

In few words, all companies invest in or apply digital solutions, over 50\% apply to risk management solutions and some apply sustainability strategies to reform the shape of the economy and society towards business evolution.

In table no. 6 respondents show high knowledge and interest in issues related to risk management and important pillars for the sustainable development of businesses that can endanger companies. The majority of respondents (60), who have a risk management plan, consider that employees are the most important pillar for sustainable development and the highest risk for business activity. For companies that do not have a risk management plan, the interest in sustainable development is divided between 3 pillars: employees (16), operational efficiency (16) and investment in research and development (16), which indicates a major investment opportunity and waste of resources, from a risk point of view, in pillars that are not so threatening to the business activity.

Table no. 6. Crosstabulation between Risk Management and Sustainable Development Strategy

\begin{tabular}{|c|c|c|c|c|c|c|c|}
\hline & \multicolumn{5}{|c|}{ Sustainable Development Strategy } & \multirow[b]{2}{*}{ हैं } \\
\hline & & 氛 & $\frac{\mathscr{d}}{\stackrel{0}{0}}$ & & 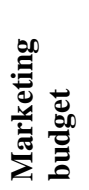 & 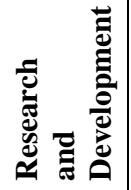 & \\
\hline \multirow{6}{*}{$\begin{array}{c}\text { Risk } \\
\text { Manag } \\
\text { ement }\end{array}$} & Number & 26 & 60 & 20 & 8 & 24 & 138 \\
\hline & $\%$ within RiskMng & $18.8 \%$ & $43.5 \%$ & $14.5 \%$ & $5.8 \%$ & $17.4 \%$ & \\
\hline & $\%$ of Total & $13.4 \%$ & $30.9 \%$ & $10.3 \%$ & $4.1 \%$ & $12.4 \%$ & $71.1 \%$ \\
\hline & Number & (c) & 16 & 16 & 2 & 16 & 56 \\
\hline & $\%$ within RiskMng & $10.7 \%$ & $28.6 \%$ & $28.6 \%$ & $3.6 \%$ & $28.6 \%$ & \\
\hline & $\%$ of Total & $3.1 \%$ & $8.2 \%$ & $8.2 \%$ & $1.0 \%$ & $8.2 \%$ & $28.9 \%$ \\
\hline \multirow{2}{*}{ Total } & Number & 32 & 76 & 36 & 10 & 40 & 194 \\
\hline & $\%$ of Total & $16.5 \%$ & $39.2 \%$ & $18.6 \%$ & $5.2 \%$ & $20.6 \%$ & $100.0 \%$ \\
\hline
\end{tabular}

Note: Percentages and totals are based on responses.

Research continues with an analysis of the connection between digitalization investment and the impact on sustainable business development (see table 7). For a better implementation of digital tools, in addition to knowledge of these tools, companies need to transform and understand the challenges, develop programs and knowledge to cope on their own. The 
survey shows similar results and interest in the influence of employees in business, and respondents allocate investment in digitalization for employee development and support, for business sustainability. Whether or not companies have an investment plan in digital tools, they all see employees as an important pillar that can influence business activity and can invest resources to support them in their activity.

Table no. 7. Crosstabulation between Investment in Digitalization and Sustainable Development Strategy

\begin{tabular}{|c|c|c|c|c|c|c|c|}
\hline & & & \multicolumn{4}{|c|}{ Sustainable Development Strategy } & \multirow[b]{2}{*}{ है } \\
\hline & & & 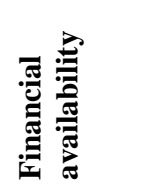 & 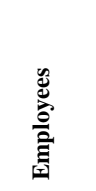 & 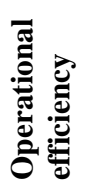 & 递 & \\
\hline \multirow{6}{*}{$\begin{array}{l}\text { Investment in } \\
\text { digitalization }\end{array}$} & \multirow{3}{*}{ yes } & Number & 26 & 56 & 22 & 32 & 144 \\
\hline & & $\begin{array}{l}\% \text { within Invest. } \\
\text { digitaliz. }\end{array}$ & $18.1 \%$ & $38.9 \%$ & $15.3 \%$ & $22.2 \%$ & \\
\hline & & $\%$ of Total & $13.4 \%$ & $28.9 \%$ & $11.3 \%$ & $16.5 \%$ & $74.2 \%$ \\
\hline & \multirow{3}{*}{ no } & Number & 6 & 20 & 14 & 8 & 50 \\
\hline & & $\begin{array}{l}\% \text { within Invest. } \\
\text { digitaliz. }\end{array}$ & $12.0 \%$ & $40.0 \%$ & $28.0 \%$ & $16.0 \%$ & \\
\hline & & $\%$ of Total & $3.1 \%$ & $10.3 \%$ & $7.2 \%$ & $4.1 \%$ & $25.8 \%$ \\
\hline \multirow{2}{*}{ Total } & & Number & 32 & 76 & 36 & 40 & 194 \\
\hline & & $\%$ of Total & $16.5 \%$ & $39.2 \%$ & $18.6 \%$ & $20.6 \%$ & $100.0 \%$ \\
\hline
\end{tabular}

Note: Percentages and totals are based on responses.

Survey information shows the companies which understand that in order to enable major business improvements, to enhance the customer experience, to create new business models or to simplify operations, companies need to use new digital technologies in a non-stop process, tools such as analytics, mobile or embedded devices. Digital assets result in the digitalization of processes, which go beyond the digitalization of information, resources, value creation and revenue growth.

\section{Conclusions}

There is a real link between increasing the capacity for international development and the capacity for innovation of SMEs. Therefore, the internationalization and development of innovative business models are considered crucial competitiveness strategies for SMEs and developing regional economies, as they are often explored together. Most companies in the economy are SMEs and should be given enough attention by researchers and forums / decision makers.

The research presents interesting facts about internationalization, knowledge about competitive development and the main pillars for achieving sustainable development in a global business economy. The results support other research on the degree of digitalization and its influence on improving internal processes and developing competitive advantage through creativity and innovation. The use of digital tools is seen as an investment process to gain agility and flexibility, especially for troubled periods of the economy, but also to help 
develop innovative processes, the result of these investments is part of profit growth. Results showing growth from local, national to international level.

Based on the analysis between Western and Eastern Europe, we have identified the following good practices to avoid the risks associated with threats from technologies and digitalization processes:

- The first stage is the development of a sustainable business model for the future, considering the technological and security structures. Starting with its own digital resources, each company has digitalization initiatives and skills that need to be catalogued and assessed. Innovation process for the design of the new model. Using cloud solutions in this process provides fast results when experimenting. The advantage of these solutions is that they keep costs under control.

- Step number two is to make a comparison between the actual performance with the potential or desired performance and the assessment of its own strengths. Therefore, it is important to analyse existing assets and strengths, but also the weaknesses of the future business model.

- Step number three is to implement digital change. In order to accelerate digital change, some traditional companies buy other companies or enter into partnerships. The emphasis is on developing the necessary technology.

- Step number four is to determine the optimal IT architecture, the central question for digital change is whether and how many applications are needed.

- Step number five is about testing old technologies, whether the old IT infrastructure can support or is compatible with the new business model.

- Step number six is a new IT architecture. "Two-speed IT" is a proven means of building a new stable foundation, a combination of old and new architecture.

- Step number seven is to establish a security strategy, the data protection strategy and data security must not only consider today's threats, but must also be prepared for future forms of attack. This requires a high degree of flexibility.

- Step number eight is to consider this transformation as an opportunity. Transformation is not only a phase with an increased risk of threat, but also offers the opportunity to improve the economic and sustainable level of the business model.

At the company or business model level, they also directly influence the areas or regions they belong to. Moreover, each country, regardless of the emerging area to which it belongs, has a special perception of the relationship between risk, innovation and sustainability, depending on the political regulations, history and predominant fields of activity.

The survey supports the idea of the need and influence of digital tools in a competitive advantage and in the development of sustainable businesses. Another important fact that emerges from the survey is the recognition and interest of developing employees and their influence on business sustainability. An interesting result is that the business environment is detrimental to open innovation and the acquisition of new technologies, more and more companies tend to change or create new business segments and develop sustainable directions. Also, management plans and risk management are increasingly merging (a large number of companies apply to develop them or include them in their existing activity). 
The main result is very clear, Innovation, Sustainability and Technology are present at all levels of companies in Western and Eastern Europe. Innovation, Sustainability and Technology are the key pillars for business model innovation.

A possible direction of development in future studies can be a research between companies in terms of turnover, a better distribution divided into small, medium and large companies. The aim is to show a more detailed overview of change and how we can avoid the risks in each market area. The study could also be complemented by an additional study covering a larger number of countries or delving deeper into the national perspective on the balance between risk and innovation.

\section{References}

Adviser Annual Report of the Government Chief Scientific, 2014. Oxford Martin. [pdf] Available at: <https://www.oxfordmartin.ox.ac.uk/downloads/reports/14-1190binnovation-managing-risk-evidence.pdf $>$ [Accessed 27 March 2020].

Audretsch, D.B., Kuratko, D.F. and Link, A.N., 2016. Dynamic entrepreneurship and technology-based innovation. Journal of Evolutionary Economics, 26(3), pp.630-620.

Berends, H., Jelinek, M., Reymen, I. and Stultiëns, R., 2013. Product Innovation Processes in Small Firms: Combining Entrepreneurial Effectuation and Managerial Causation. The Journal of Product Innovation Management, 31(3), pp.616-635.

Bhattacharya, U., Hsu, P.H., Yian, X. and Xu, Y., 2017. What affects Innovation More? Policy or Policy Uncertainty. Journal of Financial and Quantitative Analysis, 52(5), pp.1869-1901.

Bocken, N., Short, S., Rana, P. and Evans, S., 2014. A literature and practice review to develop sustainable business model archetypes. Journal of Cleaner Production, 65(15), pp.42-56.

Boer, H. and During, W.E., 2002. Innovation, what innovation? A comparison between product, process and organizational innovation. International Journal of Technology Management, 22(1/2/3), pp.83-107.

Clark, T.H. and Stoddard, D.B., 1996. Interorganizational Business Process Redesign: Merging Technological and Process Innovation. Journal of Management Information Center, 13(2), pp.9-28.

Cooper, R. and More, R., 1976. Modular risk management: an applied example. $R \& D$ Management, 9(2), pp.93-100.

Cooper, R., 1981. The components of risk in new product development: project NewProd. $R \& D$ Management, 11(2), pp.47-55.

Dabija, D.C., Bejan, B.M. and Dinu, V., 2019. How Sustainability Oriented Is Generation Z in Retail? A Literature Review. Transformations in Business \& Economics, 18(2), pp.140-155.

DigitaliseSME, 2020. Enabling the Digital Transformation of European SMEs. [pdf] Available at: <https://digitalisesme.eu/wp-content/uploads/2020/02/DigitaliseSMEFinal-Brochure-Enabling-the-Digital-Transformation-of-European-SMEs.pdf> [Accessed 24 March 2020]. 
Fisher, G., Kotha, S. and Lahiri, A., 2015. Changing with the Times: An Integrated View of Identity, Legitimacy, and New Venture Life Cycles. Academy of Management Review, 41(3), pp.383-409.

Foss, N. and Saebi, T., 2016. Fifteen Years of Research on Business model Innovation: How Far Have We Come, And Where Should We Go?. Journal of Management, 43(1), pp.200227.

Geissdoerfer, M., Vladimirova, D. and Evans, S., 2018. Sustainable business model innovation: A review. Journal of Cleaner Production, 198, pp.401-416.

Joyce, A. and Paquin, R. L., 2016. The triple layered business model canvas: A tool to design more sustainable business models. Journal of Cleaner Production, 135, pp.1474-1486.

Kallaste, M., Kalantaridis, C. and Venessar, U., 2018. Open innovation in Enterprise Strategies in Central and Eastern Europe: The Case of Estonia. Research in Economics and Business: Central and Eastern Europe, 10(2), pp.42-63.

Kennedy, S., Whiteman, G. and Ende, J.V.D., 2017. Radical Innovation for Sustainability. The power of Strategy and Open Innovation. Long Range Planning, 50(6), pp.712-725.

Kobarg, S., Stumpf-Wollersheim, J. and Welpe, I.M., 2019. More is not always better: Effect of collaboration breadth and depth on radical and incremental innovation performance at the project level. Research Policy, 48(1), pp.1-10.

Lambert, J., Nieuwenhuis, M.L. and Ehrenhard, L.P., 2018. The shift to Cloud Computing: The impact of disruptive technology on the enterprise software business ecosystem. Technological Forecasting and Social Change, 129, pp.308-313.

Lu, C. and Liu, S., 2016. Cultural Tourism O2O Business Model Innovation-A Case Study of CTrip. Journal of Electronic Commerce in Organizations, 14(2), pp.16-31.

Mantovani, A., 2006. Complementarity between product and process innovation in a monopoly setting. Economics of Innovation and New Technology, 15(3), pp.219-234.

Mateescu, R., Dinu, V. and Maftei, M., 2019. Risk Management Methods: FMEA and its Influence on Risk Handling Costs. In: Tăchiciu L., Weber G. \& Bodemann M. (eds) Building Engagement for Sustainable Development. Sustainable Management, Wertschöpfung und Effizienz. Wiesbaden: Springer Gabler.

Meidell, A.K.K., 2017. How the enterprise risk management function influences decisionmaking in the organization - A field study of a large, global oil and gas company. The British Accounting Review, 49(1), pp.39-55.

Mishra, B.K., Rolland, E., Satpathy, A. and Moore, M., 2019. A framework for enterprise risk identification and management: the resource-based view. Managerial Auditing Journal, 34(2), pp.162-188.

Nylén, D. and Holmström, J., 2015. Digital innovation strategy: A framework for diagnosing and improving digital product and service innovation. Business Horizons, 58(1), pp.57-67.

Olivia, F.L., 2016. A maturity model for enterprise risk management. International Journal of Production Economics, 173, pp. 66-79.

Pelau, C. and Chinie, A.C., 2018. Cluster Analysis for the Determination of Innovative and Sustainable Oriented Regions in Europe. Studia Universitatis , Vasile Goldis” Arad Economics Series, 28(2), pp.36-47.

Read, A., 2000. Determinants of Successful Organisational Innovation: A Review of Current Research. Journal of Management Practice,31(1) pp.95-119. 
Sadgrove, K., 2015. The Complete Guide to Business Risk Management. Third Edition London and New York: Routledge Taylor \& Francis Group.

Sahut, J.M. and Peris-Ortiz, M., 2014. Small business, innovation, and entrepreneurship. Small Business Economics, 42, pp.663-668.

Schaltegger, S., Lüdeke-Freund, F. and Hansen, E.G., 2012. Business Cases for Sustainability: The Role of Business Model Innovation for Corporate Sustainability. International Journal of Innovation and Sustainable Development, 6(2), pp.95-119.

Schepers, S., 2017. The risk averse society, a risk for innovation? In: C. Lohrmann and T. Osburg (eds.) Sustainability in a Digital World: New Opportunities Through New Technologies. Springer International Publishing, pp.21-36.

Souto, J.E., 2015. Business model innovation and business concept innovation as the context of incremental innovation and radical innovation. Tourism Management, 51, pp.142-155.

Taalbi, J., 2017. What drives innovation? Evidence from economic history. Research Policy, 46(8), pp.1437-1453.

Teece, D.J., 2010. Business Models, Business Strategy and Innovation. Long Range Planning, 43(2-3), pp.172-194.

Temel, S. and Vanhaverbeke, W., 2020. Knowledge Risk Management During Implementation of Open innovation. Knowledge Risk Management, pp.207-117.

Tohanean, D. and Zainea, N.L., 2019. Entrepreneurial challenges through innovative business models - a sigma approach. Emerging Trends in Marketing and Management, 4(1), pp. 172-181.

Tohanean, D., Toma, S.G. and Dumitru, I., 2018. Organizational Performance and Digitalization in Industry 4.0. The Journal 'Emerging Trends in Marketing and Management, 1(1), pp.282-293.

Toma, S.G., Grigore, A.M. and Marinescu, P., 2014. Economic Development and Entrepreneurship. Procedia Economic and Finance, 8, pp.436-443.

Ungureanu, M., Pop, N.A. and Ungureanu, N., 2016. Innovation and Technology Transfer for Business Development. Procedia Engineering, 149, pp.495-500.

Vasiliu, C. and Cercel, M.O., 2015. Innovation in retail: impact on creating a positive experience when buying fashion products PDF Logo. Amfiteatru Economic, 17(39), pp.2247-9104.

Wagner, M., 2017. Entrepreneurship, Innovation and Sustainability. s.l.: Greenleof Publishing.

Wheelright, S. and Clark, K., 1992. Revolutionizing Product Development, Quantum Leaps in Speed, Efficiency and Quality. New York: The Free Press.

Zhao, W., Yang, T., Hughes, K.D. and Li, Y., 2020. Entrepreneurial alertness and business model innovation: the role of entrepreneurial learning and risk perception. International Entrepreneurship and Management Journal, 23(3), pp.509-520. 